\title{
"HEIRLOOMS":
}

\section{THE EVOLUTION OF A LEGAL CONCEPT}

\author{
Norma Dawson, Professor of Law, Queen's University, Belfast
}

\section{INTRODUCTION}

In the eighteenth century, Sir Richard Hill made his daughter-in-law, Mrs Hill, an unconditional gift of some jewellery. Mrs Hill passed it on to her daughter-in-law, Ann, at her marriage to the second Viscount Hill in 1833, saying that the jewels were to be Ann's for life, but it was Mrs Hill's wish that Ann should leave them at her death "as heirlooms": a fact which Ann acknowledged years later in a memorandum to her solicitor in 1890. Ann died in 1891 leaving a will by which she bequeathed the jewels to her son, the third Viscount Hill, until his death and after his death to those who should succeed to the title successively; her intention being "that the diamonds should descend as heirlooms so far as the rules of law and equity shall permit." The third Viscount died in 1895 leaving his second wife alive, the dowager Viscountess, and a son, the fourth Viscount Hill. The fourth Viscount and his stepmother, the dowager Viscountess, asserted competing claims to the diamonds, and the former sought to recover possession of the jewels from the dowager Viscountess.

The outcome hinged on when, if at all, the jewels became "heirlooms" in any legal sense. Did that occur in 1833 when Mrs Hill asked Ann to leave the jewellery at her death "as heirlooms"? Or did it occur in 1891 when Ann's will took effect in the more complicated terms outlined above? If they became heirlooms in a legal sense in 1833, then the dowager Viscountess had an absolute interest in them, but if 1891 was the relevant date, the fourth Viscount could claim them absolutely. This was because, as we shall see later, the effect of achieving heirloom status in a legal sense at this stage of our legal history was merely to secure the descent of the property within a family for two generations. Thus, the fourth Viscount and current holder of the family title had to argue that the mere use of the word "heirlooms" in the wedding gift of 1833 had no legal force, and that the jewels only became heirlooms - and vested in him - under the 1891 will. He argued that the words used in 1833 by Mrs Hill so far as Ann had recollected them and set them down in the 1890 memorandum were words of request and not words of obligation, and that a precatory trust had not been created at that date. It was held that Ann took the jewels in 1833 free of any trust, and that the jewels only became heirlooms in any legal sense in 1891 under Ann's will. This had the effect of carrying the jewellery for two generations, through the third Viscount to the fourth Viscount whose claim was now paramount doubtless a satisfying result which preferred the claims of the heir to those of the stepmother. ${ }^{1}$

1 Hill (Viscount) v Hill (Dowager Viscountess) [1897] 1 QB 483. 
In popular usage, "heirlooms" are items of moveable property handed down from generation to generation within a family, ${ }^{2}$ often following the descent of land, at least during the seventeenth to nineteenth centuries although much less frequently so today. For the first purchaser or donor of the items within a family, who either buys them or hands them on "as heirlooms", this use of the word indicates a strong desire that future generations will respect their status by preserving them as family heritage. The ascription can even provide a moral justification for extravagance given that the initial expense of objects which might become heirlooms is offset by the potential value of the item to future generations, a point sometimes exploited by the owners of luxury brands:

"Cecil Harvell, a 39-year old Morehead City, North Carolina, attorney is the proud owner of a $\$ 17,000$ Patek Philippe wristwatch ... The company fearing its potential customers might think that an unreasonable sum to spend runs ads that encourage them to think of their purchase as creating a family heirloom: “. . . you never actually own a Patek Phillippe. You merely look after it for the next generation." The pitch seems to work: "with a seven-year old son, Mr Harvell said he viewed the watch as a keepsake that could be passed down through the family." 3 ",

The Viscount Hill case raises questions about the legal nature of "heirlooms" and the circumstances in which the word signifies not only a human aspiration but also a legal process by which moveable objects become descendible through generations. We shall consider here the legal doctrine of "heirlooms", the forces which have shaped it and the extent to which it can be said to have satisfied human aspirations through the generations.

According to Viscount Hill, the basic rule for purchasers of moveable objects seeking to preserve their integrity for future generations as chattels-with-land or as chattels within a family is that it is not sufficient merely to describe them as "heirlooms" in any disposition of the property. The request that Ann should at her death treat the jewellery as "heirlooms" and dispose of them as such was considered merely an expression of hope and insufficient to impose a precatory trust upon her. She was therefore not bound to ensure the continued descent of the jewellery to later generations (although she in fact did so). Chitty LJ commented:

“. . . a man cannot turn a chattel into freehold land [which can descend within a family by means of an entail]. Accordingly, if A gives a chattel to $\mathrm{B}$ and merely says that $\mathrm{B}$ is to have it as an heirloom, no force (in the absence of any context or special circumstance) can be attributed to the word 'heirloom'."4

Yet although merely to describe an object as an "heirloom" has, in the absence of context or special circumstance, no legal effect upon the status of

2 "Heirloom" means "a chattel that, under a will, settlement or custom, follows the devolution of real estate. Hence, any piece of personal property that has been in a family for several generations": Shorter Oxford English Dictionary.

3 Frank, Luxury Fever (1999), 16.

4 Hill (Viscount), op cit, p 496, Chitty LJ, emphasis supplied. 
the object itself, it has on occasion been considered relevant to the interpretation of gifts of other property in wills. The best example of this, perhaps, is the case of Byng $\mathrm{v}$ Byng where the House of Lords had to construe a gift of land under the will of Anne Cranmer, a descendent of Archbishop Cranmer. ${ }^{5}$ She left an estate comprising Quendon Hall in Essex to her niece "and her children", with "furniture, plate, books, linen etc, Archbishop Cranmer's portrait by Holbein, India cabinet, striking watch, and my diamond earrings as heirlooms with my estate". Under a "name and arms" clause the niece could only take the benefit of the will if she accepted an obligation to assume the Cranmer name. The issue for the court was the meaning of the words "and her children" in the gift of land and the application of the rule in Wild's Case $e^{6}$ familiar to land law students. Were these words sufficient to create an entail, given that the testatrix had failed to use the time-honoured formula "to my niece and the heirs of her body"? The normal application of the rule in Wild's Case would have suggested otherwise, resulting in the niece and her children taking the land jointly in fee simple. The rule is, however, one of construction subject to any evidence of intention collected from other parts of the will. The House of Lords relied upon the name and arms clause, the reference in the gift of chattels to "heirlooms" and specifically the desire that Holbein's portrait of Cranmer should remain at Quendon Hall, as evidence of a desire to create an entail of the land, "a wish to establish a family which shall enjoy the family estate". Lord Cranworth said that:

"the very word 'heirlooms' seems to involve in it the principle of descent ... [and] it must mean something which, though not by its own nature heritable, is to have a heritable character impressed upon it". ${ }^{7}$

Thus, in Byng, the reference to "heirlooms" and, to a lesser degree, the name and arms clause created a context of lineal descent which enabled the House of Lords to discern the donor's intention in relation to the land and find that an entail had been created.

The primary means by which moveable objects may achieve legal recognition as heirlooms and have a "heritable character impressed upon them" is through the creation of context by means of the conveyancer's art. As Theobald explains:

“. . . owners ... often desire that chattels of special interest and importance should pass from generation to generation with their . . . estates. These chattels may be family pictures, jewels and trinkets, medals and decorations, ... in fact, any chattel of interest or value. But land and chattels being fundamentally

5 (1863) 10 HLC 171. The testatrix, born Anne Webb, had inherited the estate from her cousin Martha Cranmer, subject to a name and arms clause. She changed her name to Cranmer, as did her husband at their marriage.

6 Wild's Case (1599) 6 Co Rep 16a. Prima facie, if the primary donee had no children living at the date when the will was made, the court inferred that the testator intended to create an entail whereas if a child was already in existence at that date, the primary donee took the fee simple jointly with such children as were alive when the testator died.

7 Byng, op cit, p 181. 
different, could only be welded together by the ingenuity of conveyancers, and they constantly tended to start asunder." 8

In part III, we shall consider the ingenuity of conveyancers in achieving the preservation of heirlooms within families and the role of the courts in facilitating their efforts, while in part IV, we shall examine the jurisdiction introduced in the 1880 s to authorise sale of heirlooms despite the efforts of conveyancers to prevent this. We begin by looking back to a time when "heirloom" was first used as a term of art to describe certain moveable property which devolved automatically to the heir of land according to custom or common law. Although these rules have little contemporary practical relevance, with the significant exception of those which relate to our ecclesiastical heritage, they bear brief examination since they gave us the word "heirloom" and, to an extent, they conditioned our thinking on the subject.

\section{II. “HEIRLOOM” AS A TERM OF ART}

The common law gave effect to two quite different interpretations of the term "heirloom", one established by ancient customary law but enforced by common law after the Norman Conquest and the other established by the common law itself.

\section{(a) "Heirlooms, chiefs or principals" under ancient local custom: the beginning of metaphorical annexation of moveables to land}

The common law approach to devolution of property on death rested entirely upon its own artifice, the distinction between real and personal property: real property descended to the heir-at-law determined according to the rules of primogeniture with a preference for male heirs, whilst personal property passed to the deceased's personal representatives for distribution amongst the next-of-kin. ${ }^{10}$ For several centuries, however, the common law courts showed considerable tolerance of Saxon (but not Brehon ${ }^{11}$ ) customs of inheritance which frequently challenged the principle of primogeniture and less frequently blurred the distinction between real and personal property. For example, the custom of borough-English favoured the youngest son who inherited his father's land because he was least likely to be independent at his father's death, whilst gavelkind achieved an equal distribution either amongst sons or amongst all of the deceased's children on the social basis that parents generally wish all of their children, or at least all of their sons, to benefit from their estate. ${ }^{12}$ Similar forms of customary descent could be

8 Theobald, The Law of Land (2nd ed, 1929), 227.

9 See Viner, General Abridgment of Law and Equity (2nd ed, 1793) vol 14, 291: "Note, that heirlooms, chiefs or principals are those things which have continually gone with the capital messuage by custom."

10 For comment, see Pollock and Maitland, The History of English Law before the time of Edward I (2nd ed, 1923), vol ii, bk II, ch vi, 363.

11 Case of Gavelkind (1605) Dav 134, Case of Tanistry (1607) Dav 28.

12 See First Report of the Real Property Commissioners, Brit Parl Papers (1829) x 1, and the evidence taken by the Commissioners as to the prevalence of these customs in 1829 . 
found in part of continental Europe. ${ }^{13}$ In the English context, customs prevailed on particular manors or groups of manors and the variation in tenurial customs from manor to manor was marked: in London, for example, the land of freeholders of the manor of Islington passed to the youngest son, whilst south of the river at Richmond and on surrounding manors, it was divided equally among male and female children.

Most commentators place the customary right to heirlooms squarely within the context of primogeniture, describing it generally as a right of the heir to the land to have the best ("chief" or "principal") of certain chattels of utilitarian value. Where the custom applied, on the death of a freeholder functional items such as the best bed, table, pot and other household utensils or agricultural implements would automatically pass to the heir by custom as "heir-looms". ${ }^{14}$ Coke summarised the principle thus:

"And note, that in some places chattels as heirlooms (as the best bed, table, pot, pan, cart or other dead chattels moveable) may go to the heir, and the heir in that case may have an action for them at common law ... but the heirloom is due by custom and not by the common law." 15

Such a custom went some way towards meeting an objection on economic grounds to the strict demarcation between real and personal property for purposes of devolution on death: at a time when a householder's inventory of possessions would have been extremely basic, the descent to the heir of "heirlooms" of a utilitarian nature ensured that he had some means of enjoying and exploiting the land which he inherited. ${ }^{16}$

One example of heirlooms as hereditaments descending with realty to the heir has been traced in Stretford in Oxfordshire:

"The custom of the hundred of Stretford ... is that the heirs of tenements, within the hundred aforesaid, existing after the death of their ancestors, shall have principal - i.e. an heirloom, viz., of every kind of cattle [chattel]; the best waggon, best plough, best cup, etc." ${ }^{17}$

Elton describes a Welsh custom dating back to the 10th century at the latest, whereby on the death of a landowner, the dwelling-house, eight acres of land and the best implements of the household passed to the youngest son,

13 See Elton, Origins of English History (2nd ed, 1890) ch viii, passim. Blackstone describes similar customary rights in the duchy of Brabant: Christian (ed), Blackstone's Commentaries on the Laws of England (15th ed, 1809), ii, 428 (hereafter Bl Com).

14 Halsbury's Laws of England, vol 39, para 390, Megarry and Wade, Law of Real Property (3rd ed, 1966), 531-2; Williams, Law of Personal Property (1848), 12; Noy, The Principal Grounds and Maxims; a Dialogue and Treatise of the Laws of England and on Tenures (9th ed, 1821), 239; Goodeve, The Modern Law of Real Property (1897), 11; Goodeve, The Modern Law of Personal Property (1887), 3: Tyler and Palmer (eds), Crossley Vaines on Property Law (5th ed, 1973), 9.

15 Co Litt 18b; Bl Com, op cit, p 427; 1 Cruise Dig, ss 5, 6; Williams, Mortimer and Sunnucks, Executors, Administrators and Probate (16th ed, 1982), 481-2.

16 See Pollock and Maitland, op cit.

17 Quoted from Hazlitt (ed), Blount's Tenures of Land and Customs of Manors (1874), 301. See also Myers, England in the late Middle Ages (8th ed, 1971), 63. 
presumably the heir under borough-English custom. ${ }^{18}$ It is not clear if any similar practice developed in Ireland but in Scotland "heirship moveables" were the best of certain types of moveable property to which the heir was automatically entitled. ${ }^{19}$

The term "heirloom" is itself consistent with a custom which links articles of furniture and implements with the heir to the land, since "loom" was a Saxon word for goods or chattels. ${ }^{20}$ An alternative but unconvincing interpretation that "loom" is a corruption of "limb", a view apparently accepted by Blackstone, ${ }^{21}$ was rejected in Byng v Byng. ${ }^{22}$

Objects were heirlooms when, and only when, customary law diverted the course of devolution from the mainstream created by common law: "a man by the common law cannot be heir to goods or chattels." 23 Blackstone stated:

"Heirlooms are such goods and personal chattels, as contrary to the nature of chattels, shall go by special custom to the heir along with the inheritance and not to the executor of the last proprietor." 24

The owner for the time being of heirlooms could sell or destroy them during his or her lifetime (although so great was their utilitarian value in medieval times that such conduct was extremely unlikely), but could not defeat the customary course of descent by bequeathing them to someone else. The application of such customs may have survived as late as the seventeenth or eighteenth centuries but probably were obsolescent by the end of the eighteenth century. Viner's Abridgment of 1793 described them in the present tense but in 1848, the eminent property lawyer Joshua Williams stated that "they are very seldom met." 25 The Real Property Commissioners Report of 1829 made no reference to heirloom customs although it indicated the continued prevalence of customary tenures such as gavelkind. At all events, customary modes of descent were abolished in England and Wales in

18 Elton, op cit, pp 181-2.

19 See McLaren, The Law of Wills and Succession as administered in Scotland (3rd ed, 1894), vol 1, 198.

20 Byng, op cit, n 5, p 183, Lord Cranworth.

21 Blackstone, op cit, "an heirloom is nothing else but a limb or member of the inheritance. They are generally such things as cannot be taken away without damaging or dismembering the freehold." Some support for this view can arguably be found in the decision of Holt CJ in Lord Petre v Heneage as reported by Lord Raymond: (1701) 1 Ld Raym 728. However according to another report, Holt CJ clearly viewed heirlooms as goods in gross: (1701) 12 Mod 520. In any case, Blackstone's comments seem more relevant to the issue of fixtures, and his discussion of heirlooms later proceeds on the basis that they are not physically attached to the realty: see pp 428-9.

22 Op cit, n 5, p 183.

23 Co Litt $8 \mathrm{a}$.

24 Bl Com, p 427.

25 Williams, op cit. 
$1925,{ }^{26}$ in Northern Ireland in $1955,{ }^{27}$ and in the Republic of Ireland in $1965 . .^{28}$

\section{(b) Heirlooms at common law: the "savour of the inheritance"}

The ancient Saxon customs of descent gave us the word "heirloom" and a hybrid category of chattels which on the death of an ancestor passed to the "heir". The common law courts built upon this foundation and added a slender group of common law heirlooms, ${ }^{29}$ a miscellany of items linked only by the fact that each had a close relationship with real property which on the death of a freeholder passed with the land to the heir-at-law. This occurred:

". . . where the chattels, to use the old phrase, savour of the inheritance; that is are directly connected with it. This class includes title-deeds and the chest or box where they are usually kept ${ }^{30}$ the patent creating a dignity, ${ }^{31}$ the garter and collar of a knight, ${ }^{32}$ an ancient horn where the tenure is by cornage as in the case of the Pusey horn, ${ }^{33}$ and the ancient jewels of the Crown. ${ }^{34 "} 35$

A further group of chattels was added to the sequence: coat of armour, helmets, swords and other relics hung in a church to honour the memory of an ancestor, ${ }^{36}$ a not uncommon feature in older English parish churches.

"Other personal chattels there are, which also descend to the heir in the nature of heirlooms, as a monument or tombstone in a church, or the coat-armour of his ancestor there hung up, with the pennons and other ensigns of honour, suited to his degree. In this case, albeit the freehold of the church is in the parson, and these are annexed to that freehold, yet cannot the parson or any other take them away or deface them but is liable to an action from the heir." 37

Administration of Estates Act 1925, s 45(1)(b).

27 AEA (NI) 1955, s 1(3).

28 Succession Act 1965, s11(1). In Scotland, "heirship moveables" were abolished in 1868.

29 See generally the works cited at n 14 .

30 "Writings savouring of the realty": see Duke of Somerset v Cookson (1735) 3 P Wms 390, Lord Talbot LC. Title deeds, or "the sinews of the land" as Coke described them (Co Litt 6a) and all land records and the box containing them passed at common law to the heir: Atkinson v Baker (1791) 4 TR 229 and Halsbury's Laws, vol 39, Real Property, paras 388-9.

31 And see Upton v Lord Ferrers (1801) 5 Ves Jun 801 (Lords' journals delivered to peers probably pass to their heirs).

32 In Earl of Northumberland's Case (1584) Owen 124, these bejewelled items were considered "ensigns and honours of state" which did not pass under a bequest of "jewels" by the Earl to his wife.

33 Pusey v Pusey (1684) Vern 272.

${ }^{34}$ Co Litt 18b; Bl Com, ii, 427. Blackstone explains that this is necessary to "maintain the state and support the dignity of the sovereign".

35 Hill, op cit, n 1, pp 494-5, Chitty LJ.

36 Co Litt 18b.

37 Bl Com, ii, 428-9, citing Corven's Case (1612) 12 Co Rep 105. Such items are also listed as heirlooms in Viner's Abridgment, op cit, n 9, with the observation that "this agrees with the law of other nations." 
A contemporary case, Re St Andrews, Thornhaugh, ${ }^{38}$ establishes that such heirlooms continue to devolve to the heir-at-law of the ancestor in question. In 1976, the rector and churchwardens of a village church petitioned the Consistory Court for a faculty authorising the sale of a helmet which hung in the church as part of the accoutrements of the tomb of Sir William Russell, first Duke of Bedford. Russell had been a distinguished soldier in the reign of Elizabeth I and a comrade-in-arms of Sir Philip Sydney. His helmet had at his request been put in place in the church following his death in 1613. By 1976, it was a very valuable asset the sale of which would go a long way towards meeting the church's repair bills. The court rejected the petition on the basis of lack of jurisdiction. ${ }^{39}$ The helmet belonged to Sir William's heir, but no evidence had been adduced as to that person's identity, although it was probably the present Duke of Bedford. In any event, the petitioners had not sought the Duke's consent. Further, Chancellor Fitzwalter Butler stated that jurisdiction to authorise sale of such "heirlooms" should be exercised with caution where the object is a national treasure and the sale is not absolutely necessary to raise funds to preserve the fabric of the Church. ${ }^{40}$

In each of these largely unconnected cases, the common law seized upon the heirloom principle first established by customary law - personalty devolving automatically with the realty to the heir-at-law, defying the normal course of devolution for moveables - in order to achieve the desired outcome for the case. The property in question therefore became an "heirloom" because a court decreed that the heir should have it: when original jurisdiction was first assumed for each of the examples given, heirloom status was the effect rather than the cause of the court's decree. ${ }^{41}$

Two important features of common law heirlooms survive within the legal system today. The first of these relates to English ecclesiastical heritage, as illustrated by Re St Andrews, Thornhaugh. Much work remains to be done, in the context of cultural property law, on this aspect of heirloom status and its role in the preservation of ecclesiastical heritage under the jurisdiction of the Consistory Court. The second is of more general importance. To understand it, we return to the case of the Pusey horn reported in 1684. The manor of Pusey in Berkshire had been held by the Pusey family in cornage tenure, that is, by a horn given with the land by King Canute (died 1035). This form of tenure was by no means uncommon in the Welsh Marches or the borders between England and Scotland, the stipulated service of sounding a horn being required to herald the approach of the monarch or of invading forces. The Pusey horn was inscribed:

"Kyng Knowd (Canute) gave Wyllyam Pewse [Pusey]

Thys horne to holde by thy Lande."

38 [1976] 1 All ER 154.

39 The Court had no common law jurisdiction because the heirloom belonged to Russell's heir-at-law. Statutory jurisdiction under the Faculty Jurisdiction Act 1964 only arose where the owner could not be found or withheld his consent, which was not the case here.

40 Ibid, pp 160-1 and cases cited there.

41 The example of the Crown jewels is the only one based upon mere supposition, apparently that of Lord Coke. Other jewels could not be "heirlooms" at common law: Lord Petre v Heneage, op cit, $\mathrm{n} 21$. 
Some 700 years after it had been given to William Pusey, his descendant and heir to the land, Charles Pusey, brought a bill in Chancery to recover possession of the horn from another member of the family. Blount states that the horn was produced in court, "and with universal admiration received, admitted, and proved to be the identical horn by which . . . Canute had conveyed the manor of Pusey." 42 Lord Keeper Guildford decreed that the horn must be restored to the plaintiff, ${ }^{43}$ a ruling which was to become the basis of equitable jurisdiction to order specific restitution of chattels of antiquity or unique value, an important development in Chancery given that before 1854, the common law courts had no power to award specific restitution in detinue or trover. ${ }^{44}$ During the period between Pusey in 1684 and the enactment of the Common Law Procedure Act 1854, the equitable jurisdiction to order specific restitution of moveables flourished. Thus, in 1735 the Duke of Somerset, as lord of the manor of Corbridge in Northumberland, was able to recover possession of a patera (a dish used for sacrificial offerings in ancient times) inscribed in Greek with a dedication to Hercules. By some underhand means, it had been sold to a goldsmith in Newcastle and it was feared that he might deface it in order to conceal its identity and provenance. ${ }^{45}$ Lord Talbot LC rejected the defendant's argument that the jurisdiction to award specific restitution was limited to cases of "heirlooms" strictly so-called, by which he meant objects which savoured of the realty such as the Pusey horn. It would seem that by 1735 , "heirloom" as a term of art was understood by reference to those objects which savoured of the inheritance and were categorised as heirlooms at common law rather than by reference to the earlier sense of the word under customary law. Further, the Pusey horn now appears to be retrospectively viewed as an object to be valued more for its antiquity and historic significance than for its tenurial connection with the manor of Pusey. A more general intention to protect cultural objects and not merely "heirlooms" in the narrow common law sense can be inferred in the decision in Pusey. Thus, the judgment on the bill in Pusey blossomed into a broader jurisdiction of general relevance in the field of cultural property law and explained by Lord Loughborough LC in 1796 in a case involving a unique tobacco-box belonging to a society:

"The value [of the box] I cannot measure. The Pusey horn, the patera of the Duke of Somerset, were things of that sort of value that a jury might not give two-pence beyond the weight.

42 Hazlitt (ed), Blount's Tenures, op cit, n 17, p 250 and the references found there. See also Hewitt and Richardson, (eds) White and Tudor's Leading Cases in Equity (9th ed, 1928), 404(b).

43 Pusey, op cit, $\mathrm{n} 33$.

44 The Common Law Procedure Act 1854, s 78 conferred a discretionary power to do so. See generally, Heuston (ed), Salmond on the Law of Torts (15th ed, 1969), 117, 147; Keeton and Sheridan, Equity (1969), 67-8 ,484; Megarry and Baker (eds), Snell's Principles of Equity (27th ed, 1973) 575; Meagher, Gummow and Lehane, Equity: Doctrines and Remedies (3rd ed, 1992), chap 22.

45 Duke of Somerset $\mathrm{v}$ Cookson (1735) 3 P Wms 390. 


\section{Northern Ireland Legal Quarterly [Vol. 51, No. 1]}

It was not to be cast to the estimation of people, who have not those feelings." 46

\section{THE CONVEYANCER'S ART}

"Georgian society took pride in the increasing range of material objects which were now falling within the pockets of a wider cross-section of society . . .. Many such belongings went beyond the basic necessities . . . that had made up the furnishings of so many Stuart cottages." 47

By the eighteenth century, as property ownership increasingly extended beyond the essentials of life, many more families possessed objects of value which they viewed as "heirlooms" and wanted to be treated as such in law. Inevitably, the greatest pressure for a fresh look at heirloom status would come from the wealthier families, but all property owners would benefit from the outcome. The public had grasped the essence of heirlooms descendibility of moveables - but had no understanding of the precise legal term of art and its narrow scope. Saxon custom and common law had applied only to a limited range of objects, and, in the case of customary law, had embraced articles of utilitarian value, not valuable non-essential items which were now the subject of proposed retention for the material and cultural enrichment of later generations. For property owners, "heirloom" status for chattels was an increasingly common aspiration but the legal term was wholly incapable of satisfying popular expectations. The best that could be hoped for was that lawyers might succeed in devising a means of allowing valuable moveable objects to be treated as if they were heirlooms - "quasiheirlooms", as Challis described them. ${ }^{48}$ In the context of the times, any mechanism which might be devised would require elements not only of succession to the objects in question but also of metaphorical annexation to the land on which they were to continue to be enjoyed, to ensure the unity of land and chattels.

The common law did not favour the settlement of moveable objects with or without land as estates could not created in them and, in particular, no entails of chattels were permitted: the statute De Donis Conditionalibus 1285 applied only to tenements, freehold land. Thus, an attempt to give moveables to "A for life, remainder to B and the heirs of his body", vested the whole interest in the property in A. ${ }^{49}$ By the time of Henry VI, however, the common law had drawn a distinction between bequests of moveable property per se to persons in succession and gifts by will of the use of such property. This made it possible to grant to A the use of certain chattels during his life, with a gift over of the absolute interest to vest in B at A's

46 Fells v Read (1796) 3 Ves Jun 71. See also Earl of Macclesfield v Davis (1814) $3 \mathrm{~V} \& \mathrm{~B} 16$, where specific restitution was ordered in a case of chattels made "heirlooms" by the skill of conveyancers.

47 Porter, English Society in the Eighteenth Century (1990), 225.

48 Challis, The Law of Real Property (1887), para 285.

49 Butler (ed), Fearne's Contingent Remainders and Executory Devises (10th ed, 1844), vol I, 401, 567; Halsbury's Laws, vol 42, para 611; Foley v Burnell (1783) 1 Bro CC 274 and (1785) 4 Bro PC 319, and Re Hope [1929] 2 Ch 136. 
death. ${ }^{50}$ By the 1660 s, common law and equity were at one on this point ${ }^{51}$ and by the end of the seventeenth century, it was no longer necessary to specify, at least in wills, that the property was solely "for the use of" A for life with a gift over, as these words were implied by the courts. ${ }^{52}$ The principle was summarised by Lord Keeper Somers in the Court of Chancery, as follows:

"The devise or grant of a personal thing to one for life for an hour or minute [is] a gift for ever, and an absolute disposition of the entire property to the first person. But where the devise is only of the use of the goods to one for life, and after to another, here the first devisee has not the property of the goods but only a special interest in them; and still there remains a property which may be given over." 53

Only a little more effort was necessary to secure the notional annexation of chattels to land so that succession to the chattels would follow succession to the land, at least initially. A good early example of a formula to which the Court of Chancery gave effect is found in the case of Vachel $\mathrm{v}$ Vachel and Lemmon in 1669, where after various limitations, the testator created the context for the gift of personal estate, paintings, books and rare objects:

"that they remain as an heir-loom and go and remain to such person and persons as shall inherit my said manors and lands, who I desire may prove lovers of learning, ingenuity and arts." $"{ }^{4}$

In time, the mode of settling chattels as heirlooms with land was refined by conveyancers. They could either make them expressly subject to the same limitations as the real estate setting these out in full, or they could incorporate those limitations by reference either by declaring that the chattels were to go upon the same limitations as the realty or simply by saying that they were to be treated "as heirlooms". ${ }^{55}$ Often, testators adopted the latter

50 Hyde v Parrat (1696) 2 Vern 331, 1 P Wms 1, where Lord Keeper Somers stated that equity followed the law on this point. He cited (1459) 37 Hen 6 (abridged in Bro Devise 13) where a testator devised a book called the Grail to A to use during his life and afterwards to B: held, the devise over was good. See also Welcden v Elkington (1578) Plowd 521. The cases were reviewed in Smith v Clever (1688) 2 Vern 59. Similar reasoning was applied to gifts of this sort relating to leaseholds: Manning's Case (1609) 8 Co Rep 95 and Lampet's Case (1612)10 Co Rep 47. See also Fearne, op cit, p 401, Lord Hastings v Douglas (1633) Cro Car 343 (gift of jewellery (which was the wife's paraphernalia) in husband's will: to his widow for use during her life, then over to their daughter. Held, the bequest overrode the wife's absolute right to paraphernalia at his death.).

51 Hart v Hart (1666) 1 Chan Rep 260, Vachel v Vachel and Lemmon (1669) 1 Chan Cas 727. These were both Chancery decisions in which the opinion of the common law judges was taken.

52 Fearne, op cit, p 406, Clarges v Duchess of Albermarle (1691) 2 Vern 245 and the cases cited there, Hyde, op cit, and Shirley v Ferrars (1690) 1 P Wms 6.

53 Hyde, op cit, p 3 (Peere Williams report).

54 Vachel, op cit. See also Hart, op cit, "as an heirloom according to the limitations of the lands".

55 See Lord Scarsdale v Curzon (1860 $1 \mathrm{~J} \& \mathrm{H} 39$. If no reference was made to the limitations of the real estate or to the word "heirlooms", the court would not imply 


\section{Northern Ireland Legal Quarterly [Vol. 51, No. 1]}

and simplest course, bequeathing chattels to "go as heirlooms" with the settled land.

But what did it mean to "go as heirlooms" with settled land? If the seventeenth century courts had confirmed that an element of succession to moveable objects could be achieved by limiting the rights granted to the first taker to the use of the personal property, they had done nothing to interfere with the fundamental principle that entails - descendible estates - could not be created in chattels. Where chattels were left to "go as heirlooms" and follow the succession to the entailed land, they were enjoyed by the tenant for life of the land as usufructuary and legally annexed to the settled land during the life interest(s). Thus, they could not be removed by the tenant for life. ${ }^{56}$ Title to the chattels vested absolutely in the first tenant in tail as soon as he was born subject only to the life tenant's rights as usufructuary. ${ }^{57}$ At that moment, they reverted to their status as personal property and would not descend further with the land. In several cases decided by Lord Hardwicke LC between 1740 and 1750, attempts by tenants for life to secure an absolute interest in the chattels were defeated. ${ }^{58}$ Lord Hardwicke asked rhetorically "what is there then of the nature of inheritance in these heirlooms if they stop there [ie with the tenant for life]?"59 Yet while the courts were prepared to rule that title to the moveables vested not in the tenant for life but in the tenant in tail, that vesting had to be absolute: as personal property could not be made subject to an entail, it had to stop with and vest in the first tenant in tail. On his death, the personal property formed part of his estate and passed away from the land, unless he himself took steps to resettle the chattels with the land for the benefit of his heirs, as his father or grandfather had done for him. The basic rule was explained by Lord Thurlow LC in Foley v Burnell in 1785 :

“... it was contended that the general intent of the testator was to annex the personal property in question to the real estate in the nature of heirlooms. The infant son of [the tenant for life] upon his birth acquired an estate in tail to the real property, to which these heirlooms were annexed: the extent of his interest in the heirlooms therefore was such as a tenant in tail of personal property has in consideration of law: that interest by the law is considered as absolute and of course this infant son became upon his birth the absolute owner of the property in question, subject only to the interest his father had in it for his life. ${ }^{\prime 60}$

The rule was first laid down in a series of seventeenth century Chancery cases where conveyancers' attempts to weld leaseholds on to strict

it: Wyth v Blackman (1748) 1 Ves 196 ("household stuff”). See Davidson's Precedents and Forms in Conveyancing (3rd ed, 1873), vol iii, Pt II, 1180, and Williams, Law of Personal Property (18th ed, 1926), 514-7.

56 Re Chesham (1884) 31 Ch D 466.

57 Subject to the terms of the gift, the tenant for life's right of usufruct continued until his death.

58 Gower v Grosvenor (1740) Barn C 54, Trafford v Trafford (1746) 3 Atk 348, and Duke of Bridgwater $\mathrm{v}$ Egerton (1750) 2 Ves 122.

59 Trafford, op cit, $\mathrm{p} 349$.

60 Foley, op cit, n 49, p 326. 
settlements of the real estate were given sympathetic treatment by successive Lord Chancellors. ${ }^{61}$ Leaseholds, like moveables, could not be entailed. It was logical and convenient to apply to moveables notionally annexed to land as heirlooms the same principle as had developed for leaseholds. In time, the courts even accepted that the same principle could operate where chattels were settled as heirlooms to pass with a title without specific reference to lands. ${ }^{62}$

The desire that heirlooms in the popular sense should be absorbed by the system of dynastic land settlement so prevalent in the eighteenth century emerges clearly from these words of Lord Hardwicke LC:

"The expression in the present will is, that these personal chattels shall go as heirlooms; which expression is not to be understood in the strict sense of that word, but only signifies in general, that they are to go with the rest of the family estate; and where men have settled a considerable real estate, it is frequent to find some clause in the instrument of the same kind as the present one. And if a very strict construction was made on these sort of clauses. . . it would tend very much to defeat the intention of the party. Clauses of this nature are intended as monuments of great families, to support the honour and dignity of them ..." ${ }^{63}$.

But the willingness to give effect to the intentions of testators and settlors had to operate within the general framework of property law; accordingly, "since the law will not permit personalty to go as an estate tail, when you get to such a limitation, you have to stop and give an absolute interest." ${ }^{14}$ Where land was limited to A for life, remainder to A's first and other sons successively "and the heirs male of their bodies", and the heirlooms were to pass on similar terms, absolute vesting of the chattels in A's eldest son satisfied not only the rule that entails may not be created in chattels but also the rule against perpetuities. Whether A's son was alive at the date of the gift or was born later, vesting of the heirlooms in him occurred within the period allowed by law, a life in being (the tenant for life) and 21 years.

By the early eighteenth century, the perameters of a doctrine of heirlooms had been established: judicial willingness to assist in the preservation of "the monuments of great families" (and, by extension, the favoured property of less wealthy owners) by giving effect to donors' intentions to constitute "heirlooms", bounded only by the inability to create entails in chattels and the susceptibility of heirlooms clauses to the rule against perpetuities. Although personal property could not be subjected to the same conveyancing

61 Yale (ed), Lord Nottingham's Prolegomena of Chancery and Equity (1965), 223 et seq. See the list of cases cited in Gower, op cit, especially Higgins v Derby (1708) 1 Salk 157.

${ }^{62}$ Clarke v Earl of Ormonde (1821) Jacob 791, Re Johnston (1884) 26 ChD 538, Holmesdale v West (1866) LR 3 Eq 474, and Re Exmouth (1883) 23 Ch D 158.

63 Gower, op cit, pp 56-7.

${ }^{64}$ Lord Scarsdale, op cit, n 55. Vesting of the chattels in the tenant in tail occurred even though his interest in the realty was liable to defeasance, $e g$ by the birth of someone with a better claim: Portman v Portman [1922] 2 AC 473, Re Cresswell (1883) 24 Ch D 102, Re Cornwallis (1886) 32 Ch D 388. 


\section{Northern Ireland Legal Quarterly [Vol. 51, No. 1]}

dynamic (and social stasis) as land held in entail and heirlooms clauses merely propelled personal property as far as the first tenant in tail, it was nevertheless a repeatable process which could be employed each time the land was resettled, as usually occurred every generation or two. It was enough to meet popular expectations.

The problem for the conveyancer in the early eighteenth century was that, although he knew that he could now secure the transmission of chattels as heirlooms beyond the tenant for life of the land as usufructuary to the tenant in tail, it could not be known at the outset whether the tenant in tail would live long enough to take actual possession of the land and heirlooms or leave issue to succeed him under the entail. If he died in infancy or died without issue before the entail vested in possession, the land would pass on his death to another branch of the family while the personal property, having already vested in him at birth, formed part of his estate and was severed from the land. A series of refinements in conveyancing practice led to heirloom clauses preventing vesting of the chattels from occurring if the tenant in tail died under 21 without issue and without having taken actual possession of the settled land. ${ }^{65}$ By 1740, postponement of the vesting age to 21 was "the common and known way of conveyancing" in relation to heirlooms according to Lord Hardwicke $\mathrm{LC}^{66}$ and was the practice of even longer standing in relation to leaseholds limited to follow the descent of realty. ${ }^{67}$ It was expedient to postpone vesting of heirlooms until the tenant in tail reached 21 because at that stage it was common for the tenant for life to prevail upon a tenant in tail in remainder to join with him to bar the entail and resettle the land and the heirlooms together, thus pushing back the ultimate vesting of the latter for one more generation. ${ }^{68}$

A particular difficulty arose in relation to marriage articles, the means by which much land was brought under settlement. These commonly contained covenants to settle specific chattels as heirlooms to be annexed to the land "so far as the rules of law and equity permit", so creating executory gifts the details of which remained to be settled in a later conveyance. Executory gifts might also occur under wills where the testator transferred chattels to his executors directing them to settle them as heirlooms with the land. Where the will or the marriage articles ${ }^{69}$ conferred no express reference to postponement of the vesting of the chattels in the tenant in tail until the age

65 Page-Wood V-C traces the phases in conveyancing practice in Lord Scarsdale, op cit. Where the vesting of the chattels was posponed until the tenant in tail reached 21, he could be given a right of usufruct over them until that age: eg Trafford, op cit, $\mathrm{n} 58$, where vesting of the entail in possession occurred before the tenant in tail reached 21 , it was decided that the heirlooms vested in him liable to divesting if he failed to reach the age: Re Chesham [1909] 2 Ch 329.

66 Gower, op cit, n 58, p 63.

67 Stanley v Leigh (1732) 2 P Wms 917, where Jekyll MR stated that this was wellestablished conveyancing practice.

68 See $e g$, Re Chesham, op cit.

69 In Countess of Lincoln v Duke of Newcastle (1806) 12 Ves Jun 218, Lord Eldon rejected any distinction between executory gifts by will and under covenants to settle, saying it would "shake to their foundation the rules of Equity", see also Carr v Lord Erroll (1808) 14 Ves Jun 605. As to executory gifts of heirlooms, see generally Robbins (ed), Bythewood and Jarman's Precedents in Conveyancing (4th ed, 1890), 514-7. 
of 21 or until his entail vested in possession, a question of considerable practical significance arose whether the Court of Chancery, in directing how executory gifts should be executed, should adopt current conveyancing practice which was generally to postpone vesting of the heirlooms until the age of 21 and sometimes to postpone vesting until the obtaining of actual possession of the land. In the 1740s, Lord Hardwicke LC took the view that the Court had considerable power to direct the limitations affecting settled chattels so as to ensure the unity of realty and personalty for as long as possible in accordance with the donor's wishes, as evidenced by the words "so far as the rules of law and equity permit." In the 1780s and 1790s, Lord Thurlow LC led a body of judicial opinion to the contrary and had the backing of the House of Lords for his views. ${ }^{71}$ His real objection to the Court's control over the drafting of heirlooms clauses was not the use of an age condition but the possibility that the Court might insist on the tenant in tail becoming entitled in possession to the land before taking an absolute interest in the heirlooms. What if a tenant for life in possession and a tenant in tail in remainder (often, father and son) wished to bar the entail and sell the land? The tenant in tail in remainder could not yet deal with the heirlooms, since vesting of these had been postponed. Must the heirlooms continue to be tied up even after the land had been sold or the mansion house pulled down? Lord Thurlow LC failed to see how this could be in accordance with the settlor's wishes and he persuaded his fellow judges not to adopt Lord Hardwicke's approach. Nevertheless, in 1806 in Countess of Lincoln $\mathrm{v}$ Duke of Newcastle, ${ }^{72}$ the House of Lords confirmed a decree of the Court of Chancery directing that the terms of a settlement of personalty should include a postponement of vesting until the tenant in tail was 21 even though the marriage articles in question did not expressly require this. Lord Eldon disagreed with the Lords' decision, and maintained his opposition for years to come. He agreed with Lord Hardwicke in principle but as "a great mass of property" (leases and heirlooms) had been settled on the basis of Lord Thurlow's decisions in 1785 and 1790, a return to the Hardwicke view would "shake a very large property". ${ }^{73}$ Lord Eldon's doubts, however, did not prevail. ${ }^{74}$

At the heart of this debate over the power of the Court of Chancery to adopt common conveyancing practice in relation to heirlooms clauses in executory gifts was a keen awareness on the part of the judiciary that sophisticated conveyancing could never overcome the haphazard course of human existence. On many occasions, early death of a tenant in tail or complete failure of issue of the tenant for life had frustrated conveyancers' efforts and caused a severance of heirlooms from land. Years after the debate was settled, in a case where the efforts of conveyancers to preserve the unity of land and heirlooms had proved fruitless, Lord Buckmaster would say:

Gower, op cit.

71 Foley, op cit, n 49, Vaughan v Burslem (1790) 3 Bro CC 102.

72 Countess of Lincoln, op cit.

73 Ibid, p 237. See also Burrell v Crutchley (1809) 5 Ves 544 and Carr v Lord Erroll, op cit.

74 See eg Sackville-West v Viscount Holmesdale (1871) LR 4 HL 543, Harrington v Harrington (1872) LR 5 HL 100, and Re Johnston (1884) 26 Ch D 538. 
"The result is a strange comment on the vanity of human wishes, for the absolute ownership of these heirlooms will now vest in a lady who can never become entitled to the estate which the testator desired to enrich. This is, however, due to the operation of the law which . . . is not open to dispute."75

Yet although the circumstances of individual cases would continue to perplex land owners, their conveyancers and the judges, by the end of the Georgian era all were engaged on a common purpose to preserve the integrity of land and heirlooms. When Lord Eldon LC said in 1821: "I may venture to say, that heirlooms are a kind of property that are rather favourites of the Court", ${ }^{76}$ he neatly summarised judicial attitudes towards the heritability of moveable objects of value to landed families.

The achievements of the Court of Chancery in supporting conveyancers' efforts to draft effective heirlooms clauses were recognised and respected at common law. When the heavily indebted Lord Montfort, in consideration of marriage, settled his lands and certain valuable chattels on himself for life, remainder to his wife for life, remainder to his sons successively in tail, the trustees of the marriage settlement were able to sue in trover to recover heirlooms seized from Lord Montfort by a creditor in execution of a judgment for debt. Lord Mansfield LCJ referred to the frequency with which land and heirlooms were settled on marriage and the construction which the Court of Chancery imposed upon the gift of heirlooms making Lord Montfort merely a usufructuary of the personal property, and held that any interference at common law with the remainderman's right to the settled chattels was not to be countenanced. ${ }^{77}$ Many creditors must have been defeated on this basis.

One significant development which occurred in Chancery practice in the eighteenth century was to abandon the procedure adopted in the previous century of requiring the tenant for life, at the request of the immediate ${ }^{78}$ remainderman, not only to make an inventory of the heirlooms and deliver it to the Master but also to provide security that they would be available at his or her death. ${ }^{79}$ Security was only ordered in the more settled social conditions of the eighteenth century where there appeared to be a specific threat to the continued existence of the objects in the household ${ }^{80}$

Little has been said so far about the nature of the objects which might be settled to go as heirlooms with land. The conveyancer's art could be applied to personal property in an indiscriminate manner; the law simply recognised "the propriety of annexing sufficient possessions to support the splendour of

75 Portman, op cit, n 64.

76 Clarke, op cit, n 62, p 115.

77 Cadogan v Kennet (1776) Cowp 432. See also Clarke, op cit, and Fearne, op cit, n 49, p 414.

78 But not more remote remaindermen: see Hart, op cit, n 51.

79 Vachel, op cit, n 51, Anon (1695) 2 Freem 206, and for the later practice, see the decisions of Lord Hardwicke LC in Bill v Kynaston (1740) 2 Atk 82 and Leeke v Bennett (1737) 1 Atk 470.

80 See Fearne, op cit, n 49, p 406. 
great families." ${ }^{81}$ In practice, plate, books, pictures, jewellery, statuary and similar objects were made the subject of heirlooms clauses. Items of furniture, unless of particular interest or value, were sometimes considered inappropriate to be settled as heirlooms. ${ }^{82}$ The testator or settlor might expressly refer to specific items and to the circumstances surrounding them: the disposition of "the Sèvres China flower stand given to the Rt. Hon. Robert Charles Banks, Earl of Liverpool by the Emperor Napoleon the First", for example, provided useful information about the article's provenance. ${ }^{83}$ This might be provided as an inventory attached as a schedule to the gift; alternatively, the executors or trustees might be directed to draw up an inventory of those articles among the testator's personal effects which at their discretion were to be retained as heirlooms. ${ }^{84}$

In the Victorian era, ${ }^{85}$ the issues which arose in "heirlooms" cases were mostly questions of construction of particular wills and the application of what was now regarded as settled doctrine. A degree of codification of the law was achieved in the summary of some of the earlier cases provided by Page-Wood V-C in 1860 in Lord Scarsdale v Curzon, ${ }^{86}$ a case often taken by subsequent commentators and courts as a starting-point, giving the subject of heirlooms a more modern appearance than is justified.

In general, in addressing questions of construction, the courts demonstrated a degree of benevolence towards heirlooms clauses preferring the construction which, on the facts of the case, ensured unity of land and heirlooms. In all of the nineteenth century cases where the issue was whether the settlement required the tenant in tail's estate in the land to vest in possession and not merely in remainder before the personalty vested in him, the courts reached decisions which kept land and heirlooms together. ${ }^{87}$ While superficially the twentieth century cases appear to take a more restrictive approach, the

81 Duke of Marlborough v Godolphin (1754) 1 Eden 404, 416, Sir Robert Henley, Lord Keeper.

${ }^{82}$ See Re Johnston, op cit, n 74, p 550.

83 Portman, op cit, n 64, p 481.

84 See Key and Elphinstone's Precedents in Conveyancing (15th ed, 1953) vol 2, 808; Re Johnston, op cit, and Re Montagu's Settlement Trusts [1992] 4 All ER 308. In Montagu, the trustees were directed to prepare an inventory of items suitable in their opinion for inclusion in the settlement as heirlooms and to hold the remaining personal property on trust for the tenth Duke of Manchester absolutely. They failed to prepare an inventory and allowed the Duke to have and sell several valuable items. They were found liable for breach of trust but Megarry V-C found that as the Duke had no knowledge that items had come into his power and control in breach of trust, he was not liable as constructive trustee.

85 Fiscal privileges were introduced under the Finance Act 1896, s 20 (as amended by the Finance (1909-10) Act 1910, s 63) for objects of national, scientific or historic interest, settled to be enjoyed by persons in succession: see Re Leconfield (1904) 90 LT 399 and Re Scott [1916] 2 Ch 268.

86 (1860) $1 \mathrm{~J} \& \mathrm{H} 40$.

87 Potts v Potts (1846) 9 Ir Eq R 577, confirmed by HL: (1848) 1 HLC 671; Lord Scarsdale, op cit, Martelli v Holloway (1872) LR 5 HL 532; Re Angerstein [1895] 2 Ch 883. 
outcome in almost all of these was that the heirlooms remained in the family one way or the other. ${ }^{88}$

Similar benevolence has been shown in relation to the application of the rule against perpetuities. ${ }^{89}$ The frequent use of a vesting age of 21 in heirlooms clauses potentially raised problems if successive tenants in tail died under 21 but leaving issue. Lord Eldon warned of heirlooms travelling "through minorities for two centuries." 90 Conveyancing practice was amended to address this and the House of Lords adopted a continued policy of relatively benign construction..$^{91}$ Nevertheless, conveyancers had always to be mindful of the fact that an heirlooms clause annexed moveables to an estate which enjoyed privileged status under the rule against perpetuities, privilege which did not extend to personal property. For example, a shifting clause attached to an entail was not invalidated by the rule because the entail could be barred at any time, destroying the shifting clause. The same could not be said, however, for heirlooms with the result that a shifting clause which infringed the rule against perpetuities would invalidate the gift of heirlooms, while leaving the entail intact. ${ }^{92}$ Only by the exercise of considerable skill was a limited degree of annexation achieved for heirlooms and land.

In the twentieth century, momentum in the development of heirlooms doctrine all but ceased. Such case law as has been reported mainly concerned nineteenth century or pre-World War I settlements. A small amount of litigation in the Irish courts revealed that conveyancing practice in relation to heirlooms and the attendant legal rules prevailed in Ireland, ${ }^{93}$ while an English court applied the general principles of heirlooms clauses to Scottish estates held under a deed of entail. ${ }^{94}$ Major social, economic and fiscal changes after World War I undermined the value of the strict settlement system causing conveyancers increasingly to use more flexible trust provisions crafted to comply with the rule against perpetuities (itself put on a more flexible basis in the 1960s), in order to achieve property owners' wishes. The modern trust can easily be drafted to confer rights of usufruct in

88 Chesham, op cit, n 65; Re Parker [1910] 1 Ch 581; Re Beresford-Hope [1917] 1 Ch 287; Re Lewis [1918] 2 Ch 308; Portman, op cit, n 64; Re Morrison's Settlement [1974] 1 Ch 326. Only in Re Coote [1940] 1 Ch 349 did a severance of land and chattels occur, and Morton J regretted the result: p 557. Bear in mind Lord Thurlow's concern about requiring the entail to vest in possession before the heirloom could vest: p16 ante. The same concern was expressed in Parker where Parker $\mathrm{J}$ stated that such clauses were now considered undesirable by conveyancers.

89 Christie v Gosling (1866) LR 1 HL 279; Martelli, op cit. See also Harrington v Harrington (1868) LR 3 Ch Ap 564, Portman, op cit, n 64, and Re Gormanston [1923] 1 IR 137.

90 Ware v Polhill (1805)11 Ves 257.

91 By avoidance of the requirement that the tenant in tail should vest in possession before taking his interest in heirlooms and by expressly confining entitlement to heirlooms to tenants in tail taking by purchase and not by descent. See Christie and Martelli, op cit, and compare Re Morrison, op cit, and Re Duckett [1918] 1 IR 110.

92 Portman, op cit, n 64. See Morris and Leach, The Rule against Perpetuities (2nd ed, 1962), 198-9.

93 Duckett, op cit, Beresford v Preston (1920) 54 ILTR 48, Gormanston, op cit.

94 Re Fowler [1917] 2 Ch 307. 
heirlooms on successive beneficiaries but absolute vesting must ultimately occur by the end of the perpetuity period, subject only to a further moral obligation imposed by the settlor, for example, "I desire that if any person shall become absolutely entitled to the heirlooms ... he or she will retain or settle the same as heirlooms". ${ }^{95}$ Curiously, as conveyancers turned away from strict settlements, the Law of Property Act 1925 made it possible in England and Wales for personal property to be made the subject of an entail, thus removing the restriction on the scope of De Donis Conditionalibus 1285. Indeed, after 1925, the use of the established methods of settling chattels as heirlooms described above were deemed sufficient to create an entail in such heirlooms. ${ }^{96}$ Thus, the ingenuity of conveyancers from the seventeenth century onwards lived on in the statutory provisions, albeit briefly. In the history of "heirlooms", this statutory power has been shortlived: from January 1, 1997, it has not been possible to create entails of either land or chattels in England and Wales. ${ }^{97}$

With the passage of time, "heirlooms" in the sense of specific chattels settled with land had almost completely supplanted the concept of heirlooms in the strict sense understood under customary and early common law. In the Court of Chancery in 1814, when specific restitution was sought of chattels settled as heirlooms with entailed estates, Lord Eldon LC referred to the order made in the case of the Pusey horn, (an "heirloom" in the strict sense ${ }^{98}$ ) and held that so far as the chattels at issue were concerned, "a fortiori the restitution of heirlooms must be decreed"!99 Similarly, in an Irish case reported in $1920^{100}$ where the court had to consider the terms of a gift of chattels settled as heirlooms with farm land, it was held that it could not possibly apply to utilitarian articles such as farm implements, the very articles conceived as heirlooms in Saxon custom with the endorsement of the early common law. And when in the Settled Land Act 1882, Parliament made provision for the sale, with court sanction, of chattels settled as heirlooms with land, the marginal note on the statute-book stated simply: "Heirlooms".

\section{IV. “HEIRLOOMS” UNDER THE SETTLED LAND ACT 1882: A NEW APPROACH}

Heirlooms clauses rarely granted power to sell the chattels in question and the Court of Chancery asserted no general inherent jurisdiction to authorise sale. ${ }^{101}$ The purpose of such clauses was to prevent sale, not permit it. In extreme cases, a private Act of Parliament might be obtained in order that heirlooms might be sold. ${ }^{102}$ In the 1870 s, however, the English courts assumed an inherent jurisdiction to sanction a sale of heirlooms to raise money to reduce the burden of debt on the land and so improve the life

95 See eg Re Caldwell [1971] 1 All ER 780, 783.

96 LPA 1925, s 130(1) and (2).

97 Trusts of Land and Appointment of Trustees Act 1996, Sched 1, para 5.

98 See $\mathrm{p} 9$.

99 Earl of Macclesfield, op cit, $\mathrm{n} 46$.

100 Beresford v Preston, op cit.

101 D'Eyncourt v Gregory (1876) 3 Ch D 635.

102 It appears that this occurred in the D'Eyncourt case: see Re Rivett-Carnac (1885) $30 \mathrm{ChD} 136,140$. 


\section{Northern Ireland Legal Quarterly [Vol. 51, No. 1]}

tenant's income. ${ }^{103}$ The point was not lost on the legislature for when it enacted the Settled Land Act 1882, giving the tenant for life of settled land a range of powers to free the land from the settlement by selling an absolute title and transferring the interests under the settlement from land to money, a statutory power allowing heirlooms to be sold - "a startling and new idea to any conveyancer"104- was included in the statutory scheme.

Section 37 of the 1882 Act provides as follows:

“ (1) Where personal chattels are settled on trust so as to devolve with land until a tenant in tail by purchase is born or attains the age of 21 years . . . a tenant for life of the land may sell the chattels or any of them.

(3) A sale ... of chattels under this section shall not be made without an order of the court."

Section 37 remains in force in both parts of Ireland but was replaced in England and Wales by section 67 of the Settled Land Act 1925, which is in similar terms.

The power of sale is given to the tenant for life, a mere usufructuary of the heirlooms, as we have seen. The requirement of a court order authorising sale was intended to safeguard the interests of the tenant in tail and other remaindermen. An application for an order under section 37(3) is not a routine matter: the tenant for life must make out some case for sale. ${ }^{105}$ Although he must not act on capricious, selfish or dishonest grounds - his merely seeking to increase his income to finance an extravagant lifestyle would be considered an insufficient basis for the exercise of the jurisdiction $^{106}$ - an order can be granted for the purpose of improving the settled land, ${ }^{107}$ repairing other heirlooms, ${ }^{108}$ or to reduce the debt on the settled estate. ${ }^{109}$

In addition to the tenant for life's motives, the court considers the interests of others such as owners of remainder interests and members of the family generally. This is particularly important where the heirlooms in question have a special family significance - portraits of ancestors, for example, or part of a collection of paintings built up by previous generations ${ }^{110}$ - or are objects of unique character and family pride, such as the Hope diamond

103 Fane v Fane (1876) 2 Ch D 711, referring to an unreported case, Vansittart v Vansittart, February 1876.

104 Re Duke of Marlborough's Settlement (1886) 32 ChD 1, 9, Lindley LJ.

105 Marlborough, op cit.

106 Re Hope (1893) 9 TLR 506, Re Hope [1899] 2 Ch 679, Re Bateman, The Times, June 11, 1926. Compare Re Hope (1910) 26 TLR 413 and Earl of Radnor's Will Trusts (1890) 45 Ch D 402.

107 Re Houghton Estate (1885) $30 \mathrm{ChD}$ 102, Fountaine v Barclay's Bank, unreported, April 22, 1996.

108 Re Waldegrave (1899) 81 LT 632.

109 Marlborough, op cit, Radnor, op cit, Re Beaumont (1888) 58 LT 916, Re Townshend's Settlement (1904) 89 LT 691.

110 See eg Hope (1893), order for sale refused in 1893 but granted in 1898: see Hope (1899). 
named after the family which owned it. ${ }^{111}$ The views of remote remaindermen may have counted for little in such cases, ${ }^{112}$ but those of the owner of the fee simple absolute who has barred the entail carry considerable weight. ${ }^{113}$ Between these two extremes, careful consideration has been given to the interests of remaindermen according to their degree of entitlement, but no special deference has been shown to the person who would, under an heirlooms clause, take an absolute interest, namely, the first tenant in tail to meet the conditions of that clause. ${ }^{114}$ The justification for this appears from the following statement by Lopes LJ in Re Duke of Marlborough's Settlement:

"It is clear that the tenant in tail is materially prejudiced by the exercise of the power contained in section 37. . Was the legislature alive to the effect that section 37 would have upon the tenant in tail? I think that the legislature was fully aware of what the effect would be. Section $37 .$. recognises in distinct terms the difference between the tenure of chattels and that of land; and recognises ... the fact that the law of perpetuities prevents chattels or personalty being bound to the same extent and in the same way as land." 115

And in a case where the tenant in tail was not yet born and his father was in need of additional income (with no suggestion of extravagance), so that he could take his place in society and find a spouse, Chitty LJ rebutted the arguments made on behalf of the unborn tenant in tail by saying "I am unable to see how it is in his interest to remain unborn". ${ }^{116}$

Thus, under section 37, family interests and sentiment generally, rather than the particular interests of the person who would otherwise be absolutely entitled to the heirlooms, have formed the basis of the court's discretion. And at the end of the day, the heirlooms may be sacrificed in order to preserve the land within the family, "instead of keeping heirlooms unnecessarily whilst the estate perished". .17

111 Hope (1899), op cit,: order for sale refused in 1899, but granted in 1901, see Hope (1910), op cit.

112 Hope (1910), op cit, Townshend, op cit.

113 Fountaine, op cit.

114 Re Fetherstonhaugh's Settlement (1898) SJ 198, Townshend, op cit, Radnor, op cit, Re Sebright (1912) 28 TLR 191, (1914) 31 TLR 25. The interests of infant and unborn remaindermen are represented by the trustees of the settlement.

115 Op cit, pp 11-12.

116 Radnor, op cit, p 410.

117 Marlborough, op cit, p 9, Lord Esher MR. 


\section{CONCLUSION}

An American legal scholar has commented that "there are no 'heirlooms' properly so-called in America." 118 The same might with equal justification be said of every jurisdiction except England where "heirloom" has been a legal term of art since Saxon times used only to describe utilitarian articles which by custom passed to the heir. But "heirlooms" later derived a new legal meaning which lingers today. Greater economic prosperity and an increase in the circulation of luxury items which developed in the eighteenth century created a pressure for descendible chattels despite the fact that moveables could not be entailed. The legal response was the heirlooms clause welded on to the strict settlement of land, a conveyancing device supported and encouraged by the courts. Legal force was given to gifts of chattels "to go as heirlooms" with the land, meaning "as if they were heirlooms" in the old strict sense. An entail of land or succession to a title created the context in which heirlooms clauses became enforceable. (The effective use of such a clause annexed to a title explains the ultimate destination of the heirlooms in the Viscount Hill case, considered in the opening section of this paper.)

By the late nineteenth century, statutory usage of the word "heirlooms" in the Settled Land Act 1882 - like judicial usage since the early eighteenth century - referred to chattels settled with land or a title. The 1882 Act, however, shifted the balance of power under heirlooms clauses from tenant in tail to tenant for life, and more generally it signalled the end of the era of landed estates on which heirlooms had enjoyed a privileged status. While the modern cultural heritage industry feeds on the carcase of the dynastic settlement of land and heirlooms, "heirloom" status rarely arises as a legal issue today. ${ }^{119}$ The symbiotic combination of entails and heirlooms clauses may still be created in Ireland but this is a theoretical possibility only because of the unpopularity of entails. Yet the human desire to hand property down through the generations remains. A carefully drafted modern trust will achieve this end, with or without the use of the word "heirlooms", provided that ultimate vesting does not occur beyond the perpetuity period. The use of a properly drawn heirlooms clause, at least in a gift of jewellery and perhaps more generally, will be regarded as evidence of intention to create a precatory trust, even though the gift is not annexed to an entail or to succession to a title. ${ }^{120}$ Only the unguided use of "heirlooms" in gifts or wills may still cause problems. We saw at the beginning that the request in Viscount Hill that the donee would leave jewels at her death "as heirlooms" did not impose a precatory trust creating an heirloom effect, but in Seale v Hayne, a similar gift in a will did create a trust requiring the beneficiary under the will to pass jewels on to the next generation. ${ }^{121}$ Yet in both Viscount Hill and Seale, the practical effect of the court's decision was that the jewels remained in the direct line of descent. "Heirloom" remains an

118 Gray, The Rule against Perpetuities (4th ed, 1942), para 363, n 1.

119 But see Eddis v Chichester Constable [1969] 2 All ER 912, Re Montagu's Settlement Trusts [1992] 4 All ER 308, and Fountaine v Barclay's Bank, unreported, April 22, 1996.

120 Re Steele's Will Trust [1948] 2 All ER 193, following Shelley v Shelley (1868) LR 6 Eq 540.

121 (1864) 9 LT 570. 
expression of hope, and in the limited situations now open to them, the courts still appear to be willing to find a solution which satisfies those aspirations. 